\title{
Determination of the reliability of control of curved surfaces by eddy current transducer
}

\author{
S. Tiupa ${ }^{1}$, I. Tiupa ${ }^{2}$, Salam Boussi ${ }^{3}$ \\ ${ }^{1}$ National Scientific Centre "Institute of Metrology", Myronosytska Str., 42, 61002, Kharkiv, Ukraine \\ stiupa1978@gmail.com \\ 2 Private joint stock company "Kharkivenergozbut", Plehanivska Str., 126, 61037, Kharkiv, Ukraine \\ igortyupa9@gmail.com \\ 3 Lebanese University, 6573/14, Badaro, Museum, Beirut, Lebanon \\ Salamboussi2008@hotmail.com
}

\section{Abstract}

The questions about metrological assurance and evaluation of the reliability of decision-making on the state of a metal control object during eddy current testing of surfaces with complex structure are considered in this article. The target of the research is the complex surfaces from position of their geometry and electromagnetic characteristics, that are formed on the surface of metal products during the formation of welded joints.

During the quality control of state of welded joints, first of all, the special attention is given to the identification of internal and external defects of the joint weld. However, the quality of the joint weld, from position of its mechanical characteristics, is no less affected by the shape, size and composition of the joint weld. The task of controlling the size and shape of the joint weld is quite successfully solved by applying the visual-optical method of nondestructive control. With regard to composition of the joint weld, the eddy current method of control allows to determine the composition of the material of the welded joint by measuring the magnetic and electrical characteristics of the metal.

The use of eddy current method of control allows to determine the geometrical parameters of a metal object and its electromagnetic characteristics. However, in this case, the uncertainty appears that is associated with the impossibility of determining which of the factors (the geometric dimensions of the object of control or the change in its electromagnetic characteristics), to some extent, has affected the measurement result of the signal of the eddy current transducer.

This article analyzes the influence of these factors from the point of view of their metrological characteristics and provides the formulas that allow to estimate the risks of the customer and the executor in the case of control of complex surfaces by the eddy current method.

Keywords: eddy current method; ideal object; quality; metrological assurance; reliability; welding surface.

\section{Introduction}

In the practical application of the eddy current method of quality control of electrically conductive objects with a complex surface structure, as a result of measuring informative parameters (amplitudes and phases of the output signal of the eddy current transducer), the decision on validity or non-validity of the control object (OC) is made depending on whether the monitored parameter is within the permissible limits [1]. Typical examples of such surfaces are welded joints, to which technical requirements are established regarding the dimensions of the weld bead and its surface roughness. The limited measurement accuracy of the output signals of the eddy current transducer (ECT) and the impossibility of providing ideal conditions for testing often leads to erroneous decisions, i. e. to the recognition of the object fit for operation as unfit and vice versa. In most cases, the decision is made by the operator, who in the process of control compares the signal of the eddy current transducer with a set of reference signals, i. e. signals from a weld with known geometric and mechanical characteristics [1]. In this case, the correctness of the decision will mainly depend on the qualifications of the operator and the possibility of producing standard samples.

The objective of this work is to obtain dependencies for calculating the reliability of control of welded joints, taking into account the metrological characteristics of the instruments and the characteristics of the welded joint.

\section{Research results}

When adjusting the sensitivity of the eddy current transducer to the expected surface size, standard samples simulating the surface of the welded joint are used as a reference measure [2]. At the same time, in the process of monitoring an unknown parameter (height, length, width), the excess (or compliance) of the ECT 
signal level is fixed above the ECT signal level from the corresponding model weld [3].

From the point of view of the measuring procedure, in this case the differential method of comparison with the measure is used. The relative error of the result of the comparison with the reference measure satisfies the expression:

$$
\delta X=\frac{a}{X} \delta И+\delta M,
$$

where $\delta X$ - relative instrumental error of the measuring device; $\delta M-$ the relative error in the calibration of the measure, i. e. related to nominal value $X M ; a=X-X M-$ the difference between the measure and the real object.

In this case, when comparing the amplitude of the signals of the eddy current transducer from a real object and a reference sample, in the case of using the amplitude method, one can set the dependence of the relative error in determining the size of the weld in the form:

$$
\delta U=\sqrt{\left(\frac{a}{U_{\mathrm{w}}} \delta U_{\mathrm{w}}\right)^{2}+\left(\delta U_{\mathrm{st}}\right)^{2}},
$$

where $\delta U-$ the relative error of comparing the size of the real and the reference surface, or else, the error of comparing the correspondence of the level of the ECT signal of unknown size against the corresponding size of the reference sample; $\delta U_{\mathrm{w}}-$ the relative error in measuring the amplitude of the output voltage of ECT from the real surface of the weld; $\delta U_{\text {st }}-$ the relative error in measuring the output voltage from the ideal surface of the standard sample; $a=U_{\mathrm{w}}-\delta U_{\mathrm{st}}-$ the difference between the signals of the converter from the real and the reference surface.

Obviously, for the case of using the phase method of defect control with eddy current transducer, a similar relationship can be established for the error of comparing the phase signal:

$$
\delta \varphi=\frac{a}{\varphi_{\mathrm{w}}} \delta \varphi_{\mathrm{w}}+\delta \varphi_{\mathrm{st}},
$$

where $\delta \varphi-$ the relative error of comparing the phase of the output signal of the ECT from the real and ideal surface of the standard sample; $\delta \varphi_{\mathrm{w}}-$ the relative error in measuring the phase of the ECT signal from the real surface of the weld; $\delta \varphi_{\mathrm{st}}$ - the relative error in measuring the phase of the signal from the ideal surface of a standard sample; $a=\varphi_{\mathrm{w}}-\varphi_{\mathrm{st}}-$ the phase difference between the signals from the real and the reference surface.

As it can be seen, formulas (2) and (3) are identical and reflect the behavior of comparison errors of an unknown parameter of the weld surface with a model surface when using an amplitude or phase control method. A similar expression can be written for the case of representing the complex signal EMF of the eddy current transducer on the oscilloscope screen in the complex plane.

Let's carry out an analysis of the error components of determining the characteristic size of a curved surface using the example of determining the height of a weld bead by measured ECT signals (amplitude, phase, complex EMF) with the amplitude method and the basic formula (2).

The measurand, namely the nature of the amplitude of the signal from the real and the reference surface, is a complex and often uncertain function of the form:

$$
\begin{aligned}
& U_{\mathrm{w}}=f\left(H, \omega,\{Q\}, \mu_{\mathrm{rw}}, \sigma_{\mathrm{w}}, l_{\mathrm{w}}, h_{\mathrm{w}}, d_{\mathrm{w}}\right), \\
& U_{\mathrm{st}}=f\left(H, \omega,\{Q\}, \mu_{\mathrm{rst}}, \sigma_{\mathrm{st}}, l_{\mathrm{st}}, h_{\mathrm{st}}, d_{\mathrm{st}}\right),
\end{aligned}
$$

where $H-$ the intensity of the probe sample of the electromagnetic field; $\omega$ - cyclic frequency of a variable in time probing electromagnetic field; $\{Q\}-$ a set characterizing the converter parameters (dimensions and mutual arrangement of the coils, the distance to the sample, parameters of the windings of the coils, etc.); $\mu_{\mathrm{rw}}, \sigma_{\mathrm{w}}-$ relative magnetic permeability and specific electrical conductivity of the material of the object under study; $\mu_{\text {rst }}, \sigma_{\text {st }}-$ electromagnetic characteristics of the standard object; $l_{\mathrm{w}}, h_{\mathrm{w}}, d_{\mathrm{w}}$ and $l_{\mathrm{st}}$, $h_{\mathrm{st}}, d_{\mathrm{st}}-$ geometric dimensions of the investigated and reference surface.

The difference $a$ between the signals from the real and the reference surface in the numerator of expression (2) characterizes the degree of proximity of the signals and serves as a criterion for the correspondence of the dimensions of the studied surface to the reference surface [4]. In expressions $(4,5)$, the magnetic field $H$, the frequency $\omega$, the set of transducer parameters $\{Q\}$, as well as the parameters of the measuring circuits of the control circuits, when the experiment procedure is carried out correctly, are stable and have the same effect on the measurement result of the voltage of the ECT signal from the reference and real surface. In this case, the expression for the results of comparison $a$ will have the following form:

$a=U_{\mathrm{w}}\left(\mu_{\mathrm{rw}}, \sigma_{\mathrm{w}}, l_{\mathrm{w}}, h_{\mathrm{w}}, d_{\mathrm{w}}\right)-U_{\mathrm{st}}\left(\mu_{\mathrm{rst}}, \sigma_{\mathrm{st}}, l_{\mathrm{st}}, h_{\mathrm{st}}, d_{\mathrm{st}}\right)$.

In this case, the signal from the reference curved surface has a strictly determinate character, the signal from the real surface is a random variable, which is a function of the geometric parameters of the weld bead and the sample material with five degrees of freedom [5]. Typically, variables $\mu_{\mathrm{rst}}, \sigma_{\mathrm{st}}, l_{\mathrm{st}}, h_{\mathrm{st}}, d_{\mathrm{st}}$ can take specific fixed values in a narrow range of the measurand; in the general case, variables $\mu_{\mathrm{rw}}, \sigma_{\mathrm{w}}, l_{\mathrm{w}}, h_{\mathrm{w}}, d_{\mathrm{w}}$ are continuous functions of the corresponding parameter.

In this case, it is possible to minimize the value $a$, provided that one or a number of sets $\left\{U_{\mathrm{st}}\left(\mu_{\mathrm{rst}}, \sigma_{\mathrm{st}}, l_{\mathrm{st}}, h_{\mathrm{st}}, d_{\mathrm{st}}\right)\right\}$ are matched to the set, which can be realized by enumerating the corresponding parameters. 
The probability of making a decision that the unknown size of a curved surface in terms of parameters corresponds to one of a number of reference ones, it is necessary that the relative comparison error is equal (close in magnitude) to the relative measurement error of the signal from the reference surface (according to formula (2)).

$$
\left|\delta U-\delta U_{\text {st }}\right|=\min .
$$

For example, as a characteristic size of a curved surface, we take the characteristic of the heights of the weld bead. The decision on whether the parameters of the curved surface, namely the height of the weld bead, satisfy condition (7) is taken according to the results of monitoring the output signal of the ECT based on the ratio:

$$
h_{\mathrm{iw}}=h_{\mathrm{ist}}+\delta_{\mathrm{iw}},
$$

where $\delta_{\mathrm{iw}}-$ error in measuring the height of the weld bead; $h_{\text {ist }}-$ actual value of the height of the weld bead, which is determined by the visual-optical method.

Due to the limited accuracy of eddy current control, it is impossible to make an unmistakable decision about the true value of the height of the weld bead. According to the results of measuring the ECT signal, the possible values of the parameter $h_{\mathrm{iw}}$ can be evaluated, the probability density distribution of which is determined by the formula [6]:

$$
f_{\mathrm{i}}\left(h_{\mathrm{ist}} / h_{\mathrm{iw}}\right)=\frac{f_{\mathrm{i}}\left(h_{\mathrm{ist}}\right) q_{\mathrm{i}}\left(h_{\mathrm{iw}}-h_{\mathrm{ist}}\right)}{\int_{-\infty}^{\infty} f_{\mathrm{i}}\left(h_{\mathrm{ist}}\right) q_{\mathrm{i}}\left(h_{\mathrm{iw}}-h_{\mathrm{ist}}\right) d h_{\mathrm{ist}}} \approx q_{\mathrm{i}}\left(\delta_{\mathrm{iw}}\right) \text {, }
$$

where $f_{\mathrm{i}}$ - probability density distribution of the controlled parameter; $\delta_{\mathrm{iw}}-$ probability density distribution of measurement error $h_{\mathrm{iw}}$.

This formula is valid for statistically independent parameters $\delta_{\text {iw }}$ and $h_{\text {ist }}$ as the rate of change $f_{\mathrm{i}}\left(h_{\text {ist }}\right)$ is quite small.

Due to the finite accuracy of measuring the ECT signals, as well as the methodological errors embedded in the conversion function that connects the geometric parameters of the weld bead and the ECT signals, two types of errors are possible during control [7]:

1) recognition of the height of the weld bead such that satisfies the condition (8), which in reality is not such, or otherwise - the risk of the customer $R_{\mathrm{c}}$;

2) rejection of a suitable control object - manufacturer's risk $R_{\mathrm{im}}$.

These risks can be managed both by reducing the measurement error and by narrowing the control tolerances.

If the measurement results lie on the border of permissible values, the individual risks $R_{\mathrm{c}}$ and $R_{\mathrm{m}}$ cannot be made smaller than $1 / 2$ irrespectively to the extent of increase of the measurement accuracy. Also, with the removal of the controlled parameter $h_{\mathrm{iw}}$, the risks become dependent on the distribution $f_{\mathrm{i}}\left(h_{\text {iss }}\right)$. Taking this into account, it is advisable to introduce the concept of averaged customer's risk and manufacturer's risk:

$$
\begin{aligned}
& \bar{R}_{\mathrm{c}}=1-\frac{\int_{\mathrm{A}}^{\mathrm{B}} \int_{\mathrm{A}}^{\mathrm{B}} f\left(h_{\mathrm{ist}}\right) q\left(h_{\mathrm{iw}}-h_{\mathrm{ist}}\right) d h_{\mathrm{w}} d h_{\mathrm{st}}}{\int_{-\infty}^{\mathrm{B}} \int_{\mathrm{A}} f\left(h_{\mathrm{ist}}\right) q\left(h_{\mathrm{iw}}-h_{\mathrm{ist}}\right) d h_{\mathrm{w}} d h_{\mathrm{st}}}, \\
& \bar{R}_{\mathrm{m}}=1-\frac{\int_{\mathrm{A}}^{\mathrm{B}} \int_{\mathrm{A}}^{\mathrm{B}} f\left(h_{\mathrm{ist}}\right) q\left(h_{\mathrm{iw}}-h_{\mathrm{ist}}\right) d h_{\mathrm{w}} d h_{\mathrm{st}}}{\int_{\mathrm{A}}^{\mathrm{B}} f\left(h_{\mathrm{ist}}\right) d h_{\mathrm{st}}},
\end{aligned}
$$

where $A$ and $B-$ lower and upper limits of acceptable values for the height of the weld bead.

As it can be seen from the formulas for calculating risks and choosing the required control accuracy, it is necessary to know the probability density distribution of the controlled parameter $f\left(h_{\text {ist }}\right)$.

The random size of the height of the weld bead, subject to the welding technology, must comply with the geometric characteristics of the permissible limits that are established by the regulatory documentation for the performance of certain types of work. In this case, the normal distribution of the probability density can serve as a model of the behavior of the controlled parameter.

The height of the weld bead $h_{\mathrm{iw}}$ is estimated by the output (amplitude and phase) of the ECT signal. Since the ECT signal depends on a large number of factors, namely $U_{\mathrm{w}}=f\left(H, \omega,\{Q\}, \mu_{\mathrm{rw}}, \sigma_{\mathrm{w}}, l_{\mathrm{w}}, h_{\mathrm{w}}, d_{\mathrm{w}}\right)$, we will consider the distribution law of random errors in determining the height of the weld bead at different points on the surface to be normal.

$$
q\left(\delta_{\text {iw }}\right)=\frac{1}{\sqrt{2 \pi} \sigma} e^{-\frac{\left(\delta_{\mathrm{iw}} \delta_{\text {iwaver }}\right)^{2}}{2 \sigma^{2}}},
$$

where $\delta_{\text {iwaver }}-$ the average value of the error in determining the height of the weld bead; $\sigma$ - standard deviation $\delta_{\text {iwaver }}$.

\section{Summary}

Classically, the distribution parameters $\delta_{\text {iwaver }}$ and $\sigma$ are determined by the statistical processing of multiple measurements, i. e. during experiments with a wide variety of characteristic sizes of curved surfaces. The implementation of this approach is technically very complicated and requires the manufacturing of a wide range of reference surfaces on materials with known electromagnetic properties, as well as the conditions of the experiment (intensity, field frequency), sizes of ECT coils. In the future, it is necessary to replace the complex and expensive procedures for the manufacturing of model surfaces by modeling the ECT signals based on theoretical studies of the interaction of ECT with curved surfaces with desired properties. 


\title{
Визначення достовірності контролю криволінійних поверхонь вихрострумовим перетворювачем
}

\author{
С.Ю. Тюпа 1 , І.В. Тюпа², Салам Буссі ${ }^{3}$ \\ 1 Національний науковий центр "Інститут метрології", вул. Мироносицька, 42, 61002, Харків, Україна \\ stiupa1978@gmail.com \\ 2 Приватне акціонерне товариство "Харківенергозбут”, вул. Плеханівська, 126, 61037, Харків, Україна \\ igortyupa9@gmail.com \\ з Ліванський державний університет, 6573/14 Бадаро, Музей, Бейрут, Ліван \\ Salamboussi2008@hotmail.com
}

\section{Анотація}

У статті розглядаються питання щодо метрологічного забезпечення та оцінки достовірності прийняття рішень про стан металевого об'єкта контролю під час проведення вихрострумових випробувань поверхонь зі складною структурою. Об'єктом дослідження є складні, з точки зору геометрії та електромагнітних характеристик, поверхні, які утворюються на поверхні металевих виробів під час формування зварних з'єднань.

У процесі проведення контролю якості стану зварного з'єднання в першу чергу особлива увага приділяється виявленню внутрішніх та зовнішніх дефектів зварного шва. Однак на якість зварного з'єднання, з точки зору його механічних характеристик, не меншим чином впливають форма, розмір та склад зварного шва. Завдання контролю розміру та форми зварного шва цілком успішно вирішується шляхом застосування візуально-оптичного методу неруйнівного контролю. Що стосується складу зварного шва, то вихрострумовий метод контролю дозволяє визначати склад матеріалу зварного з’єднання шляхом вимірювання магнітних та електричних характеристик металу.

Існують однозначні кореляційні зв'язки між електромагнітними та механічними характеристиками металу. Застосування вихрострумового методу контролю дозволяє визначати геометричні параметри металевого об’єкта та його електромагнітні характеристики. Однак у цьому випадку з'являється певна невизначеність, пов'язана з неможливістю визначення, який із факторів (геометричні розміри об'єкта або зміна його електромагнітних характеристик) тією чи іншою мірою вплинув на результати вимірювання сигналу вихрострумового перетворювача.

У роботі проведено аналіз впливу цих факторів з точки зору їх метрологічних характеристик та наведено формули, які дозволяють оцінити ризики замовника та виконавця у разі контролю складних поверхонь вихрострумовим методом.

Ключові слова: вихрострумовий метод; ідеальний об’єкт; якість; метрологічне забезпечення; надійність; зварна поверхня.

\section{Определение достоверности контроля криволинейных поверхностей вихретоковым преобразователем}

\author{
С.Ю. Тюпа ${ }^{1}$, И.В. Тюпа², Салам Бусси³ \\ 1 Национальный научный центр "Институт метрологии", ул. Мироносицкая, 42, 61002, Харьков, Украина \\ stiupa1978@gmail.com \\ 2 Частное акционерное общество “Харьковэнергосбыт”, ул. Плехановская, 126, 61037, Харьков, Украина \\ igortyupa9@gmail.com \\ з Ливанский государственный университет, 6573/14 Бадаро, Музей, Бейрут, Ливан \\ Salamboussi2008@hotmail.com
}

\section{Аннотация}

Рассматриваются вопросы метрологического обеспечения и оценки достоверности принятия решений о состоянии металлического объекта контроля при вихретоковых испытаниях сложных поверхностей. Объектом исследования являются сложные с точки зрения геометрии и электромагнитных характеристик поверхности, которые образуются на поверхности металлических изделий при формировании сварных соединений.

При контроле качества состояния сварного соединения в первую очередь особое внимание уделяется выявлению внутренних и внешних дефектов сварного шва. Однако на качество сварного соединения с точки зрения его механических характеристик в не меньшей степени влияют форма, размер и состав сварного шва. Задача контроля 
размера и формы сварного шва вполне успешно решается применением визуально-оптического метода неразрушающего контроля. Что касается состава сварного шва, то вихретоковый метод контроля позволяет определять состав материала сварного соединения путем измерения магнитных и электрических характеристик металла.

Применение вихретокового метода контроля позволяет определять геометрические параметры металлического объекта и его электромагнитные характеристики. Однако в этом случае появляется неопределенность, связанная с невозможностью определения, какой из факторов (геометрические размеры объекта или изменение его электромагнитных характеристик) в той или иной мере повлиял на результат измерения сигнала вихретокового преобразователя.

Проанализировано влияние данных факторов с точки зрения их метрологических характеристик и приведены формулы, которые позволяют оценить риски заказчика и исполнителя в случае контроля сложных поверхностей вихретоковым методом.

Ключевые слова: вихретоковый метод; идеальный объект; качество; метрологическое обеспечение; надежность; сварочная поверхность.

\section{References}

1. Kluev V.V. (Ed.). Nerazrushaiucshiy control [Nondestructive control]. Vol. 2. Moscow, Mashinostroenie Publ., 2003. 688 p. (in Russian).

2. Babadzhanov L.S., Babadzhanova M. L. Mery i obraztsy v oblasti nerazrushaiucshego controlya [Measures and reference materials in the field of nondestructive control]. Moscow, Standartinform Publ., 2007. 208 p. (in Russian).

3. Konovalov N. N. Normirovanie defectov i dostovernost nerazrushaiucshego controlya svarnyh soedinenii [Normalization of defects and reliability of nondestructive control of joint welds]. Moscow, NTC "Promyshlennaya bezopasnost" Publ., 2004, 132 p. (in Russian).

4. Stavroulakis G. E. Inverse and crack identification problems in engineering mechanics. Berlin, Springer, 2001. 240 p.
5. Gorkunov B. M., Tiupa I. V., Skopenko V.V., Shakhin I.H. Veroyatnostnye podkhody k opredeleniyu razmerov defectov vikhretokovym metodom [Probabilistic approaches to sizing of defects by eddy current method]. Tekhnichna electrodinamica. Tem. vypusk "Silova electronika ta energoefectivnist" [Technical Electrodynamics. Subject issue "Power Electronics and Energy Efficiency"], 2011, part 2, pp. 231-234 (in Russian).

6. Zakharov I. P., Kukush V. D. Teoriya neopredelennosti $\mathrm{v}$ izmereniyah [Theory of uncertainty in measurements]. Kharkov, KONSUM Publ., 2002. $256 \mathrm{p}$.

7. Chinkov V.M. Osnovy metrologii ta vymiruvalnoi tekhniky [Fundamentals of metrology and measurement technics]. 2-nd edition. Kharkiv, NTU "KhPI" Publ., 2005. 524 p. (in Ukrainian). 